Rev. Biol. Trop. 46(4): 1069-1079, 1998

www.ucr.ac.cr www.ots.ac.cr www.ots.duke.edu

\title{
Generic Composition, Structure and Diversity of Secondary Forests at Amisconde, the Pacific Slope of the Cordillera de Talamanca, Costa Rica
}

\author{
D. A. P. Hooftman
}

Institute for Environmental Sciences, University of Zürich, Winterturerstrasse 190, CH-8057 Zürich, Switzerland. Fax: + 4116355711 ; hooftman@uwinst.unizh.ch

Received 13-XI-1997. Corrected 8-VII-1998. Accepted 14-VIII-1998.

\begin{abstract}
Most Costa Rican forests have been intensively studied in recent years. One exception is the transition zone from lowland wet forest to the high elevation Quercus forest belt at the pacific slopes of the Cordillera de Talamanca. An inventory of secondary forest composition, structure and diversity was done on a specific slope (1150-2300-m elevation) in the conservation and development project Amisconde. Thirteen plots of $500 \mathrm{~m}^{2}$ were evenly spread along an elevation gradient. Specimens were collected of all woody individuals $(>3 \mathrm{~cm} \mathrm{DBH})$, dried, placed in a herbarium of morphospecies and afterwards identified. In total 90 genera within 49 families were found. The vegetation was separated in three forest ty pes using TWINSPAN classification. Forest types were elevation based. Elevation and forest age showed (overall) no correlation with diversity using ANOVA, with the single exception of a positive correlation of the number of genera and elevation. This was opposite to the negative correlations mostly found on elevation gradients. The main factors for this positive correlation were the level of recent disturbance and the distance to primary forest, in combination with forest age.
\end{abstract}

Key words: Amisconde, elevation gradient, forest typology, generic diversity, secondary forest, Talamanca.

Costa Rican forests are intensively studied; complete inventories exist out of most many parts of the country. Forest structure descriptions can be found, among others, of La Selva biological station (Mcdade et al. 1994 and more recently e.g.: Clark \& Clark 1996, Guariguata et al. 1997, Laska 1997 with a nice overview of the forest understory structure), the slopes of volcano Barva (Heaney \& Proctor 1990) and the Monteverde cloud forest reserve on the higher Tilaran ridge (Lawton \& Dryer 1980, Nadkarni et al. 1995, Matelson et al. 1995). A study on the lower part of the Tilaran ridge is currently is progress (Hooftman, Bongers \& Watson, unpublished data). Recently the high elevation Quercus forest belt of the Cordillera de Talamanca has been under intensive research (Jiménez et al. 1988, van Velsen et al. 1993, Kappelle 1996).
One of the forests not described recently is the transition zone from lowland wet forest to this Quercus forest belt on the western Talamanca ridge, a highly interesting zone with influences from both lowland and high elevation forests.

To fill this gap I present in this paper the generic vegetation structure, composition and diversity of the secondary forest in this transition zone (1000-2300 m). Here, human pressure is rather high, resulting in high deforestation rates of primary forest leading to severe soil erosion and land degradation (Sader \& Joyce 1988). In protecting and conserving the soil and overall vegetation on the steep irregular slopes on the pacific site of the Cordillera de Talamanca, secondary forest play a very important role (Calvo Alvarado et al. 1993). For this reason, it is necessary to know its floristic composition, structure and 
diversity. Knowledge of forest structure is a necessary tool for understanding forest dynamics (Nadkarni et al. 1995) and thus possible protection functions. The Centro Cientifico Tropical in Costa Rica (V. Watson, pers com.) has recently stressed the need for such vital knowledge in this area.

Next to forest type zonation along an elevation gradient $I$ will correlate the changing diversity, plot based, with an elevation gradient. Diversity along a elevation gradient is mostly assumed to decrease with elevation, as stressed by different authors (Cleef et al. 1984, Gentry 1988, Kappelle et al. 1995a) although contrasting results are reported in forest edge situations on high altitudes in Costa Rica (van Velsen et al. 1993). I will discuss the found correlation for this specific secondary forest studied.

\section{MATERIALS AND METHODS}

Site: The study area was located on the south-west facing Pacific slopes of the Cordillera de Talamanca in southern Costa Rica, in the bufferzone of the La Amistad Biosphere Reserve and Chirripó National Park. The forest inventory took place in an $\pm 8 \mathrm{~km} 2$ range $(515$ 517 East and 364-368 North, Lambert coordinates Costa Rica), in the conservation and development project Amisconde (La AMIStad CONservation and DEvelopment), situated around the village San Jeronimo de San Pedro (Peréz Zeledón canton, San José province). The Centro Cientifico Tropical in San José coordinates the project. Because of the steep and irregular slopes and the large amount of yearly rain $(2000-3000 \mathrm{~mm})$, the area is vulnerable to severe soil erosion (Calvo Alvarado et al. 1993). Forests on this slope were mainly secondary forests aging 10 to 40 years (oral information from farmers); elevation of the studied plots was between 1100-2300 meters. Forests regenerated mainly at frequently burned pasture grounds used for cattle grazing with only few remnants of prior vegetation (mainly Quercus, Ocotea and Ficus)
Floristic sampling: I distributed plots to the best possible extent evenly along an elevation gradient, using aerial photograph interpretation (photographs taken in 1992) and conversations with local farmers and Amisconde staff. Plots contained a buffer zone of at least 20 meters to all signs of recent human forest disturbance.

Plots size was $500 \mathrm{~m}^{2} \quad(50 * 10 \mathrm{~m})$, perpendicular to the exposition of the slope, with the shorter site following the contour line. Within the plot all woody individuals $>3 \mathrm{~cm}$ DBH (Diameter Breast Height) were measured in two diameter classes: $3 \mathrm{~cm} £ \mathrm{DBH} £ 10 \mathrm{~cm}$ and $\geq 10 \mathrm{~cm} \mathrm{DBH}$. The larger class was measured at the whole plot, the smaller at half the plot (stem-density and basal area doubled afterwards). The diameter distinction is modified from Clark (1994, see also Hooftman 1995).

Of each woody individual a specimen was collected. Those were dried and gathered in a herbarium of morphospecies. Main criteria for classification were the general position of the leaves on the branch, raw leaf morphology and other specific leaf features. Morphospecies were identified with the help of taxonomists at INBio in Heredia (Q. Jiménez and J.F. Morales); in addition the Amisconde staff provided help as well as local people with knowledge of vernacular species names. The herbarium was afterwards donated to a local school for education purposes. Several morphospecies could not be identified to generic level; in the TWINSPAN classification those morphospecies were not omitted. Taxonomic nomenclature follows mainly Kappelle (1996) with additions from manual de la flora Costa Rica (INBio, Costa Rica).

Vegetation classification: A rough vegetation table was made using basal area and stem density per genus. Subsequently by using box-plots, assumed remnant individuals from previous vegetation were omitted from the data set. Excluded were several large Ficus and Quercus trees (minimal cut-off: $\mathrm{DBH}>70$ $\mathrm{cm})$. Subsequently I discovered that other 
researchers had used the same cutoff (Lugo \& Brown 1992, Clark \& Clark 1996), finding it a useful diameter criterion (Clark \& Clark 1996). The raw vegetation table was treated using the multivariate cluster analysis program TWINSPAN (Jongman et al. 1987) in order to identify possible secondary forest communities (called types in this study). In addition I used the cluster analysis program DENDRO, with a Sörensen dissimilarity index. Forerunning TWINSPAN the vegetation table was converted into eight TWINSPAN cut level classes. This conversion followed a logarithmic octave scale proposed by Gauch (1982) and given in Kappelle et al. (1994). A TWINSPAN analysis was conducted for both basal area and stem density data per genus, using socioecological groups of genera. Nomenclature of vegetation types is provisional and analogue to Kappelle et al. (1994).

The two different TWINSPAN classifications showed no major differences. Several minor changes occurred in socioecological group structure. In this paper I will use further the classification based on basal area per genus, shown in Appendix 1 . Differences between the forest types were tested with the use of a student- $t$ test. Trends $(p$ $<0.1)$ were seen as differentiating between forest types.

Gradient analysis: The successional stage of the forest and elevation were correlated with diversity using ANOVA and regression techniques. Total basal area per plot was used as a parameter for estimating the secondary forest stage. A positive relation between forest age and the increase of basal area in young secondary forest was assumed. This relation has been observed among others in the Talamanca area by Kappelle et al. (1995b).

Generic diversity of secondary forest plots was calculated in three ways. Firstly, this was done by using the number of individual genera per plot and subsequently by calculating the Shannon-Wiener index of species diversity per plot on basis of both basal area and the number of individual stems per genus. The Shannon-
Wiener index of species diversity (Hs) algorithm used follows Magnurran (1988) and will be further referred to as Shannon-index.

\section{RESULTS}

General species composition: In the study area 13 secondary forest plots were made (plot names in order of measurement: AM). Forests were between 8 and $15 \mathrm{~m}$ tall, standing on slopes ranging from $38 \%$ to $95 \%$. 90 genera within 49 families were identified. Most common genera on the slope of the ridge were Cornus and Mollinedia. Other important genera in the area are Quercus (in higher areas), Ocotea, Sorocea (in lower areas), Protium, Toxicodendron and the shrub Palicourea. However, dominance of any genus rarely exceeded $20 \%$ of local basal area within plots. A complete overview of all genera with their abundance can be found in Appendix 1 . Diameter distribution showed a clear J-shape pattern for all forests (data not shown) suggesting a good regeneration potential.

TWINSPAN classification revealed three forest types within the secondary forest (Table 1). The second clustering technique, using a Sörensen dissimilarity analysis, obtained the same result, with only minor differences in similarity levels due to difference in algorithm (Fig. 1). Elevation was most likely to be the most important determining factor in combination with forest age and local disturbance. An outlier was plot $\mathrm{M}$ that, according to the dendrogram, had a very low similarity with other plots. For elevation reasons, this plot was put in the lowest forest type.

\section{Secondary forest types description:}

\section{1: Quercus-Cleyera forest}

The elevation range of this secondary forest type is ca $2000-2300 \mathrm{~m}$. It was characterized by a clear presence of Quercus and Cleyera, covering 10-15\% of the total basal area in this zone. Other distinctive genera in this forest type were Rauwolfia, Styrax, Picramnia and Citharexylum. 


\section{TABLE 1}

Forest types revealed by TWINSPAN classification and plots (exact location of plots on the slope is not given in this paper but can be given upon request by the author)

Forest Type (code)

Quercus-Cleyera forest (1)

Clusia-Cornus forest (2)

Cecropia-Inga forest (3)
Plots

F, G, H, I, J, K

$\mathrm{C}, \mathrm{D}, \mathrm{E}$

A, B, L, M

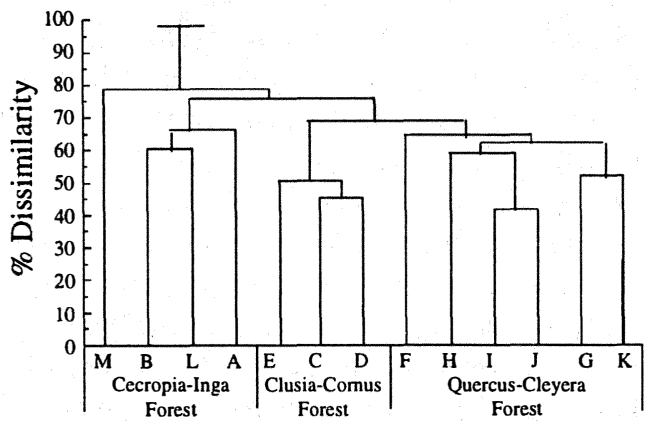

Fig.1. Dendrogram of dissimilarity between plots, using a Sörensen (present/non-present) index based on basal area data.

The Quercus-Cleyera forest was very dense with a compact undergrowth layer of several bamboo and shrub species. The forest floor contained a thick layer of organic material, inhabiting large amounts of herbs. This suggests compiled with a higher basal area (ns.) the presence of a rather older secondary forest compared to the CecropiaInga forest at lower elevation. Stem density $(\mathrm{DBH}>3 \mathrm{~cm})$ was higher than in the Cecropia- Inga forest type $(\mathrm{p}<0.029)$ and the Clusia-Cornus forest type $(p<0.085)$. Slope and exposition of all forest types showed no significant differences.

\section{2: Clusia-Cornus forest}

The Clusia-Cornus forest contains elements of both the Quercus-Cleyera type and the Cecropia-Inga type but did not include the most distinctive species of these groups. It can be seen as a transition zone between the other two forest types with its own characteristics.
Elevation was 1500-1750 m. The genus Clusia was abundantly present. Cornus reached its optimum distribution in this forest, as does Sorocea. Other important present genera were Ocotea, Toxicodendron, Ilex, Mollinedia and the edible dwarfpalm Geonoma. Stands were more open with less individual stems $(\mathrm{p}<0.085)$, a less thick undergrowth and herb layer, compared to the Quercus-Cleyera forest type.

\section{3: Cecropia-Inga forest}

Cecropia-Inga forest $(1150-1500 \mathrm{~m}$ elevation) is distinguished by the present of the pantropical pioneer genus Cecropia in association with the distinctive genus Inga. Other prominent genera in this belt were Sorocea, Cornus, Mollinedia and Protium. Most genera reported within this belt were seen in low but more even distributions (4.6 stems per genus $/ 500 \mathrm{~m}^{2}$; Quercus-Cleyera type: 5.6 stems per genus $/ 500 \mathrm{~m}^{2}$ )

The Cecropia-Inga forest plots contained fewer genera $(\mathrm{p}<0.011)$, individuals $(\mathrm{p}<0.029)$ and basal area (ns.) than the Quercus-Cleyera forest type. In addition, no abundant undergrowth was found, the litter layer was thin and contained mostly fresh leafs. This, and the presence of the distinctive pioneer Cecropia indicates a younger, recently more disturbed secondary forest.

Diversity: I found in the Quercus-Cleyera forest type 67 genera of woody species within 45 families, in the Clusia-Cornus forest 45 (31 families) and in the Cecropia-Inga forest 53 (35 families). However, this was measured with an uneven distribution of plots for the different forest types (Table 1), therefore comparing the forest types was done by using averages per plot. Fig. 2 gives an overview of the number of genera and the average diversity of the three forest types. As already stated the forest types differed most in quantity of genera and less in calibrated diversity (Shannonindex). The Quercus-Cleyera forest contained more genera $(\mathrm{p}<0.085)$ and a higher diversity 
( $\mathrm{p}<0.012$, basal area based) than the transition Clusia-Cornus forest and the Cecropia- Inga forest (respectively $p<0.011$ and $p<0.066$ ). No differences between diversity in the QuercusCleyera forest and the Cecropia-Inga forest type were found. This was mainly caused by the already observed more even distribution of genera over the stem density in the CecropiaInga forest compared to in the QuercusCleyera forest. The Quercus-Cleyera forest contained a more clumped distribution of genera over the area.
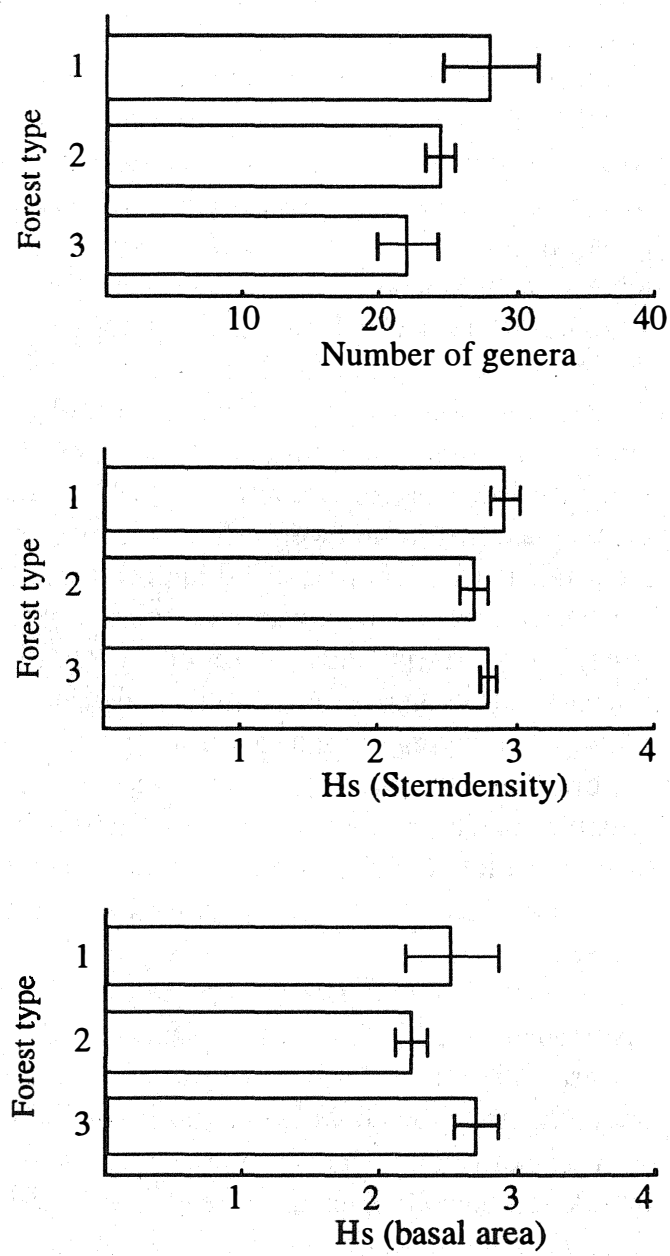

Fig. 2. Average forest type descriptives (per $500 \mathrm{~m}^{2}$ ): a: number of genera; $b$ : Shannon index based on basis stem density per genus; c: Shannon index based on basal area per genus.
Diversity along a successional and elevation gradient: In this paper the successional stage of the forest plots was estimated using the basal area of the separate plots. No significant correlation between basal area and number of genera and diversity was found. The same accounts for Shannon-index values along the elevation gradient. The amount of genera appeared to increase significantly with altitude ( $\mathrm{p}<0.01$, Fig. 3 ). The Quercus-Cleyera forest type contained a significantly higher number of genera compared to the Clusia-Cornus and the Cecropia-Inga forest.

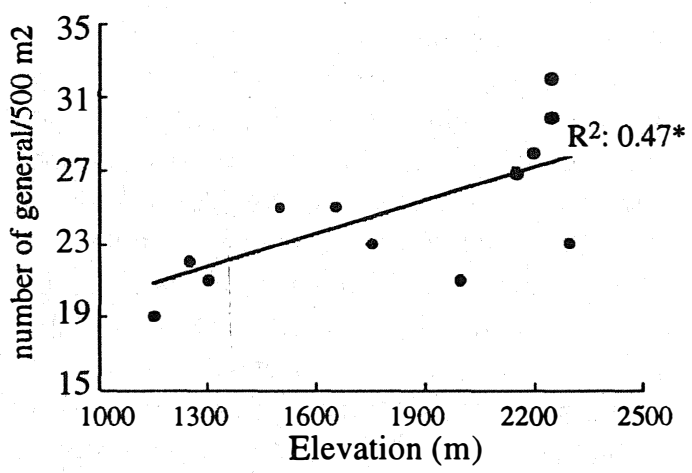

Fig. 3. Changing number of genera in $500 \mathrm{~m}^{2}$ plots with increasing elevation.

\section{DISCUSSION}

Forest zonation: Recent studies on the cordillera de Talamanca (Jiménez et al. 1988, Orozco 1991, Kappelle et al. 1994, Kappelle et al. 1995b) overviewed mainly vegetation composition above 2000 -m elevation, referred to in general as Ocotea-Quercus forest (Kappelle et al. 1994, Kappelle et al. 1995b). Comparing especially the Quercus-Cleyera forest type described in this paper to Kappelle's studies, including Van Velsen et al. (1993), many important genera appear to be in common in a similar abundance: Quercus, Cleyera, Viburnum, Clusia, Cornus and several genera in the Lauraceae (Ocotea, Persea, Nectandra). The clear similarities between the upper Quercus-Cleyera forest in this study and the lower Freziera-Quercus 
(Kappelle et al. 1994) forest zone suggest that the altitudinal zonation found in the Amisconde area corresponds to the lower part of the spectrum of secondary forestzonation of the Ocotea-Quercus forest. Gathering more data, preferably on species level, is needed to provide us a better insight on forest belt zonation within this area. This for example by means of using the same cluster analysis for the whole elevation gradient on the Talamanca ridge on species levels $(1100-3000 \mathrm{~m}$ elevation). I checked only woody individuals in this study, consequently the quantity of genera is difficult to compare with the earlier mentioned studies on Talamanca, those include mostly all vascular species (see van Velsen et al. 1993, Kappelle 1996). Similar studies on protected montane forest in Northern Costa Rica, revealed a similar number of genera in the Monteverde cloud forest reserve (Nadkarni et al. 1995) and clearly less genera on volcano Barva (Heaney \& Proctor 1990). This states the value of this, mostly not protected, transition zone from lowland forest to true montane forest of high elevation on the Talamanca ridge, although the mentioned studied used less elevation differences but a larger sampling areas.

Factors influencing generic diversity: Recent studies in the Cordillera de Talamanca showed a decrease in species richness with increasing altitude (Kappelle et al. 1995a). A relation also showed in the Colombian Andes (Cleef et al. 1984). In this study one notes the opposite, a positive correlation between number of genera and elevation. This opposite relation was also found by Van Velsen et al. (1993) but they included all vascular species and credited this to migrating paramo herbs and ferns species into herb- and forblands at approx. 2800 meters, this situation is not similar to this study. Measuring only woody species as done here would also exclude the herbs immigrating from the pasture grounds into the forest edges, a process clearly visible in these Talamancan forests (M. ten Hoopen \& M. Kappelle, pers com.). To explain the positive correlation several (cooperating) explanations are possible, including forest age, the level of disturbance in recent history and most likely the distance to primary forest. Those explanations are discussed below in this.

Unfortunately local farmers did not provide reliable information about land use history. No written recordings were made and several families were only for a short period of time in the area. No correlation was found between basal area and floristic composition, in which basal area is supposed to be a good indication for age in younger successional forest. However, by using other indications I think that the Cecropia-Inga forest type is possibly younger than the Quercus-Cleyera forest. With younger I mean a smaller timespan of secondary growth after abandonment of a specific area after utilization (assumed to be cattle grazing). Younger secondary forests mainly include fewer species than older forest stands. A important indicator is the presence of the genus Cecropia which is a very light demanding short living pioneers, able to grow only in full light conditions and very rarely seen in close forests (Lamprecht 1989). The genus was only found within lower elevation plots but it was reported up to approximately $2000 \mathrm{~m}$ in the Amisconde area on other slopes (internal Amisconde report, S.T.). Furthermore, Kappelle (1996) did report Cecropia in young secondary forest up to 2300 meters elevation on the Cordillera de Talamanca. The absence of Cecropia in higher elevation plots (1500-2300 m) may be a clear indication of an older successional age of those forests.

A further factor is the type and level of disturbance in the secondary forests. The research area is a bufferzone in which tree cutting is not allowed. However until 1993, the start of Amisconde project (meaning a more intensive controlling in the forest) illegal tree fellings were common practice inside those forest (pers obs. and pers com. with Amisconde staff). In addition small-scale fires, set for agricultural purposes, repeatedly affected the forest. The remnants of those 
disturbances are likely to be higher in the lower elevation forest patches, near the villages, and not in the inaccessible higher situated patches near the edge of the Biosphere reserve Amsistad (walking distance 2-3 hours of the village with very unclear trails). A possible mechanism is that in low altitude patches, shade tolerating late successional tree species were constantly outcompeted, if not cut, by light demanding pioneer species due to unusual large gaps, resulting in a possible retrogressive and delayed succession, a process clearly shown on the lower slopes of Tilaran (Hooftman, Bongers \& Watson, unpublished data).

A more ecological factor influencing higher levels of diversity in high elevation plots in this area is the geographical distance to the primary forest and thus possible isolation from seed flux. Primary forests in the area occur at higher altitudes (ca. $2500 \mathrm{~m}$, pers obs.) and are montane Quercus forest. As stated by Purata (1986) and Kappelle et al. (1996) succession is speeded up in conditions close to a primary forest. Further away from the mature stands succession may develop much slower due to reduced seed dispersal by birds (among others: Guevara et al. 1986, Robinson \& Handel 1993, Heitz Siefert et al. 1996, Wilms \& Kappelle, unpublished data). Furthermore those primary Quercus forest contain presumably other species than would establish in those lower forest, which would mean that seed and flux from other genera than present in the forest is very scarce. The further distance from seed sources compiled with the earlier mentioned factors would be a clear explanation of the positive elevation-diversity correlation found within this study.

\section{ACKNOWLEDGMENTS}

The data were collected in cooperation with the Agricultural University Wageningen (Frans Bongers and R. de Graaf) and Centro Cientifico Tropical, San José, Costa Rica (Vicente Watson and co-workers), I am very thankful for their help. I am grateful to Maarten Kappelle for reading previous versions of this manuscript. Without the help of the Amisconde staff (Luis Morillo and coworkers) and my field assistants, this study had not been possible. The INBio in Heredia was very kind in helping with the identification of collected specimens. This study was finished at the Institute for Environmental Sciences of the University of Zürich, Switzerland.

\section{REFERENCES}

Calvo-Alvarado, L. 1993. Plan maestro de proyecto AMISCONDE-Costa Rica. Centro Cientifico Tropical, San José, Costa Rica. 108 p.

Clark, D. A. 1994. Plant demography. p. 90-105. In L. A. Mcdade, K. S. Bawa, H. A. Hespenheide \& G. S. Hartshorn (ed.). La Selva. The University of Chicago, Chicago, Illinois.

Clark, D. B. \& D. A. Clark. 1996. Abundance, growth and mortality of very large trees in neotropical lowland rain forest. Forest Ecol. and Manage. 80: 235-244.

Cleef, A. M., O. Rangel, T. van der Hammen \& R. Jaramillo. 1984. La vegetacion de las selvas del transecto Buritaca. p. 267-406. In T. van der Hammen \& P. M. Ruiz (ed.).La Siera Nevada de Santa Marta (Columbia), Transecto Buritaca - La Cumbre. J. Cramer, Vaduz, Luxembourg.

Gauch, H. G. 1982. Multivariate analysis in community ecology. Cambridge University, Cambridge, UK. 298 p.

Gentry, A. H. 1988. Changes in plant community diversity and floristic composition on environmental and geographical gradients. Ann. of the Missouri Bot. Garden 75: 1-34.

Guariguata, M. R., R. L. Chazdon, J. S. Denslow, J. M. Dupuy \& L. Anderson. 1997. Structure and floristics of secondary and old growth forest stands in lowland Costa Rica. Plant Ecol. 132: 107-120.

Guevara, S., S. E. Purata \& E. van der Maarel. 1986. The role of remnant forest trees in tropical secondary succession. Vegetatio 66: 77-84.

Heaney, A. \& J. Proctor. 1990. Preliminary studies on forest structure and floristics on volcan Brava, Costa Rica. J. Trop. Ecol. 6: 307-320. 
Heitz-Siefert, U., P. Heitz \& S. Guevara. 1996. Epiphyte vegetation and diversity on remnant trees after forest clearance in southern Veracruz, Mexico. Biol. Conserv. 75: 103-111.

Hooftman, D. A. P. 1995. The seed bank of young successional forest in Costa Rica. M.Sc-thesis. Agricultural University Wageningen, Wageningen, Netherlands.

Jiménez, R. H. G., R. Chavarri, R. Miranda \& I. Rojas. 1988. Aproximaciones silviculurales al manejo de un robledal (Quercus spp) en San Gerardo de Dota, Costa Rica. Turrialba. 38: 208-214.

Jongman, R. H. G., C. F. J. ter Braak \& O. F. R. van Tongeren. 1987. Data analysis in community and landscape ecology. Pudoc, Wageningen, Netherlands. 299 p.

Kappelle, M. 1996. Los Bosques de Roble (Quercus) de la Cordillera de Talamanca, Costa Rica: Biodiversidad, Ecologia, Conservacion y Desarollo. University of Amsterdam, Amsterdam, Netherlands. 318 p.

Kappelle, M., H. P. van Velzen \& W. H. Wijtzes. 1994. Plant communities of montane secondary vegetation in the cordillera de Talamanca, Costa Rica. Phytocoerologia 22: 449-484.

Kappelle, M., J. G. van Uffelen \& A. M. Cleef. 1995a. Altitudinal zonation of montane Quercus forest along two transects in the Chirripó National Pork, Costa Rica. Vegetatio 119: 119-153.

Kappelle, M., P. A. F. Kennis \& R. A. J. de Vries. 1995b. Changes in diversity along a successional gradient in Costa Rican upper montane Quercus forest. Biodiv. Conserv. 4: 10-34

Kappelle, M., M. T. Geuze, M. Leal \& A. M. Cleef. 1996. Successional age and forest structure in a Costa Rican montane Quercus forest. J. Trop. Ecol. 12: 681-698.

Lamprecht, H. 1989. Silviculture in the tropics. Paul Parey, Hamburg, Germany. 318 p.
Laska, M. S. 1997. Structure of understory shrub assemblages in adjacent secondary and old growth tropical wet forest, Costa Rica. Biotropica 29: 2937.

Lawton, R. O. \& V. Dryer. 1980. The vegetation of the Monteverde cloud forest reserve. Brenesia. 18: 101116.

Lugo, A. E. \& S. Brown. 1992. Tropical forest as sinks of atmospheric carbon. Forest Ecol. and Manage. 54: 239-255.

Magnurran, A. E. 1988. Ecological diversity and its measurements. Croom Helm, London, UK. 179 p.

Matelson, T. J., N. M. Nadkarni \& R. Solano. 1995. Tree damage and annual mortality in a montane forest in Monteverde, Costa Rica. Biotropica 27: 441-447.

Mcdade, L. A., K. S. Bawa, H. A. Hespenheide \& G. S. Hartshom. 1994. La Selva. The University of Chicago , Chicago, Illinois. 486p.

Nadkarni, N. M., T. J. Matelson \& W. A. Haber. 1995. Structural characteristics and floristic composition of a neotropical Cloud Forest, Monteverde, Costa Rica. J. Trop. Ecol. 11: 481-495.

Purata, S. E. 1986. Floristic and structural changes during old-field succession in the Mexican tropics in relation to site history and species availability. $\mathrm{J}$. Trop. Ecol. 20: 11-19.

Robinson, G. R. \& S. N. Handel. 1993. Forest restoration on a closed landfill rapid addition of new species by bird dispersal. Conserv. Biol. 7: 271-278.

Sader, S. A. \& A. T. Joyce. 1988. Deforestation rates and trends in Costa Rica, 1940 to 1983. Biotropica 20: 11-19.

Van Velzen, H. P., W. H. Wijtzes \& M. Kappelle. 1993. List of secondary vegetation species of the Pacific montane belt, Cordillera de Talamanca, Costa Rica. Brenesia 39-40: 147-161. 
Appendix 1

TWINSPAN classification of secondary forest types in the Amisconde area, Costa Rica, with genera in socio-ecological

Groups.

Forest type:

Plot:

Altitude:

Slope(\%):

Genera (\#):

TWINSPAN-

division
1

$\begin{array}{llllll}\text { H } & \text { K } & \text { F } & \text { G } & \text { I } & \text { J } \\ 2 & 2 & 2 & 2 & 2 & 2 \\ 2 & 3 & 0 & 2 & 2 & 1 \\ 5 & 0 & 0 & 0 & 5 & 5 \\ 0 & 0 & 0 & 0 & 0 & 0\end{array}$

E C D

11

$\begin{array}{lll}7 & 5 & 6 \\ 5 & 0 & 5\end{array}$

00

3

$\begin{array}{lllllllllllll}3 & 8 & 7 & 9 & 6 & 7 & 7 & 4 & 7 & 6 & 3 & 6 & 6 \\ 8 & 3 & 0 & 5 & 0 & 8 & 7 & 0 & 0 & 3 & 6 & 0 & 3 \\ 3 & 2 & 2 & 2 & 3 & 2 & 2 & 2 & 2 & 2 & 2 & 1 & 2 \\ 1 & 3 & 1 & 9 & 4 & 9 & 4 & 6 & 5 & 3 & 1 & 9 & 2 \\ & & & & & & & & & & & & \\ 0 & 0 & 0 & 0 & 0 & 0 & 0 & 0 & 0 & 1 & 1 & 1 & 1 \\ 0 & 0 & 0 & 0 & 0 & 0 & 1 & 1 & 1 & 0 & 0 & 0 & 1\end{array}$

\begin{tabular}{|c|c|c|c|c|c|c|c|c|c|c|c|c|c|c|c|}
\hline Trichilia & Meliaceae & 4 & - & - & - & - & - & - & - & - & - & - & - & - & 000 \\
\hline Aiouea & Lauraceae & - & - & - & 1 & 2 & 1 & - & - & - & - & - & - & - & 000 \\
\hline Alchornea & Euphorbiaceae & - & - & - & 3 & - & - & - & - & - & - & - & - & - & 000 \\
\hline borillo & - & - & - & - & - & - & 2 & - & - & - & - & - & - & - & 000 \\
\hline Citharexylum & Verbenaceae & 2 & - & - & - & 3 & 2 & - & - & - & - & - & - & 1 & 000 \\
\hline Cleyera & Theaceae & 4 & 3 & 4 & 2 & - & 2 & 3 & 1 & - & - & - & - & - & 000 \\
\hline Crossopetalum & Celastraceae & 2 & - & - & - & - & - & - & - & - & - & - & - & - & 000 \\
\hline Goethalsia & Tiliaceae & 6 & - & - & - & - & - & - & - & - & - & - & - & - & 000 \\
\hline Guatteria & Annonaceae & - & - & 3 & 3 & 1 & - & - & - & - & - & - & - & - & 000 \\
\hline Koanophyllon & Asteraceae & - & - & - & - & 2 & - & - & - & - & - & - & - & - & 000 \\
\hline Licania & Chrysobalaceae & - & - & - & 3 & - & - & - & - & - & - & - & - & - & 000 \\
\hline Magnolia & Magnoliaceae & - & - & - & - & 1 & - & - & - & - & - & - & - & - & 000 \\
\hline Myrcia & Myrtaceae & 4 & - & - & - & - & - & - & - & - & - & - & - & - & 000 \\
\hline Myrsine & Myrsinaceae & - & 3 & - & - & - & - & - & - & - & - & - & - & - & 000 \\
\hline Oreopanax & Araliaceae & - & - & - & - & - & 1 & - & - & - & - & - & - & - & 000 \\
\hline Perrottetia & Celastraceae & - & - & 3 & 3 & - & - & - & - & - & - & - & - & - & 000 \\
\hline Picramnia & Simaroubaceae & 3 & - & - & 1 & 3 & 1 & - & - & - & - & - & - & - & 000 \\
\hline Pouteria & Sapotaceae & - & - & 1 & 4 & 1 & - & 1 & - & - & - & - & - & - & 000 \\
\hline Psychotria & Rubiaceae & 3 & 2 & - & 3 & 5 & 2 & - & - & - & 1 & 1 & - & 1 & 000 \\
\hline Quercus & Fagaceae & 3 & 7 & 5 & 6 & 3 & 6 & 5 & - & - & - & - & - & - & 000 \\
\hline Rondeletia & Rubiaceae & 2 & 4 & 1 & 2 & 6 & 4 & 6 & 1 & 2 & - & - & - & 1 & 000 \\
\hline Roupala & Proteaceae & - & - & - & 5 & - & - & - & - & - & - & - & - & - & 000 \\
\hline Rauwolfia & Apocynaceae & 1 & - & 4 & 1 & 1 & 4 & - & - & - & - & - & - & - & 000 \\
\hline Rubus & Rosaceae & 2 & - & - & - & - & - & - & - & - & - & - & - & - & 000 \\
\hline Styrax & Styracaceae & - & - & 4 & 5 & 3 & - & - & - & - & - & - & 2 & - & 000 \\
\hline Ulmus & Ulmaceae & - & 4 & - & - & - & - & - & - & - & - & - & - & - & 000 \\
\hline Allophylus & Sapindaceae & - & - & - & - & 1 & - & - & 3 & - & - & - & - & - & 001 \\
\hline Fuchsia & Onagraceae & - & - & - & - & - & - & - & - & 1 & - & - & - & - & 001 \\
\hline Ocotea & Lauraceae & 2 & - & 5 & 5 & 1 & - & 2 & 4 & 4 & - & - & 3 & - & 001 \\
\hline Sapium & Euphorbiaceae & 1 & - & - & - & - & - & - & 2 & 5 & - & - & - & - & 001 \\
\hline Zanthoxylum & Rutaceae & 2 & - & - & - & - & - & - & 3 & - & - & - & - & - & 001 \\
\hline
\end{tabular}




\begin{tabular}{|c|c|c|c|c|c|c|c|c|c|c|c|c|c|c|c|}
\hline Asteraceae & Asteraceae & - & - & - & - & - & - & 1 & - & -. & - & - & - & - & 001 \\
\hline Bidens & Asteraceae & - & - & - & - & - & - & 4 & - & - & - & - & - & - & 001 \\
\hline Calatola & Icacinaceae & - & - & - & - & 2 & - & - & 2 & - & - & - & - & - & 001 \\
\hline Clusia & Clusiaceae & 1 & 5 & - & - & - & - & 2 & 2 & 2 & - & - & - & - & 001 \\
\hline Dendropanax & Araliaceae & 2 & 1 & 4 & - & - & - & - & - & 3 & - & - & - & - & 001 \\
\hline Gaiadendron & Loranthaceae & 3 & 3 & - & - & - & - & 4 & - & - & 1 & - & 1 & - & 001 \\
\hline Pterdophyta & Pterdophyta (order) & - & - & 1 & 1 & 1 & 2 & - & 1 & 2 & - & 1 & - & - & 001 \\
\hline Hyeronima & Euphorbiaceae & 1 & - & 1 & - & 3 & 4 & - & 5 & 3 & - & - & - & - & 001 \\
\hline Nectandra & Lauraceae & 3 & - & 1 & 3 & - & - & 1 & - & 3 & - & - & - & - & 001 \\
\hline Solanum & Solanaceae & - & - & - & - & - & - & 1 & - & - & - & - & - & - & 001 \\
\hline Geonoma & Arecaceae & 1 & - & - & 1 & - & 1 & 3 & 1 & 2 & - & - & - & - & 001 \\
\hline Tiliaceae & Tiliaceae & - & - & - & - & - & - & - & 1 & - & - & - & - & - & 001 \\
\hline Toxicodendron & Anarcardiaceae & - & 4 & - & 2 & 5 & 1 & 2 & 2 & 4 & - & - & - & 2 & 001 \\
\hline Gonzalagunia & Rubiaceae & - & - & - & - & - & - & 2 & - & 4 & - & - & - & - & 001 \\
\hline Ficus & Moraceae & 2 & 1 & 1 & - & 4 & 5 & 1 & 1 & - & 6 & - & - & - & 010 \\
\hline Ehretia & Boraginaceae & 4 & - & - & - & - & - & - & - & - & - & 2 & - & - & 010 \\
\hline Myrcianthes & Myrtaceae & - & - & - & 1 & 1 & - & - & - & - & - & - & - & 1 & 010 \\
\hline Protium & Burseraceae & - & - & 1 & 2 & 4 & 6 & - & 1 & 2 & - & 4 & - & 5 & 010 \\
\hline Tovomitopsis & Clusiaceae & 3 & - & 2 & 3 & 3 & 3 & - & - & - & 1 & 3 & - & - & 010 \\
\hline Viburnum & Caprifoliaceae & 2 & 4 & - & - & 1 & 2 & - & - & - & 2 & - & 1 & - & 010 \\
\hline Cornus & Cornaceae & - & - & - & 5 & 4 & 1 & 4 & 6 & 2 & 5 & - & - & 4 & 011 \\
\hline Ilex & Aquifoliaceae & - & - & - & - & - & 3 & - & 4 & 2 & 2 & - & - & - & 011 \\
\hline Mollinedia & Monimiaceae & - & 1 & 6 & - & 1 & 3 & 3 & 3 & 3 & - & - & 3 & 5 & 011 \\
\hline Palicourea & Rubiaceae & 1 & 1 & 3 & - & 4 & 2 & - & 3 & 1 & 3 & 1 & - & - & 011 \\
\hline Unidentified & - & 6 & 3 & 6 & 2 & 4 & 4 & 4 & 5 & 3 & 2 & 4 & 7 & 4 & 011 \\
\hline Eugenia & Myrtaceae & - & 3 & 1 & 2 & - & - & - & - & - & 4 & - & - & - & 100 \\
\hline Saurauia & Actinidiaceae & - & - & - & 2 & 1 & 1 & 3 & - & - & - & 4 & - & - & 100 \\
\hline volvarillo & - & - & 2 & - & 2 & 2 & 1 & - & - & - & - & - & 4 & - & 100 \\
\hline Rubiaceae & Rubiaceae & - & 2 & 5 & 2 & - & 2 & - & - & - & 1 & 4 & - & 2 & 100 \\
\hline Cedrela & Meliaceae & 5 & - & - & - & - & - & - & - & - & 2 & - & - & 3 & 101 \\
\hline Trema & Ulmaceae & - & - & - & - & - & 4 & - & - & - & - & 4 & - & - & 101 \\
\hline Sorocea & Moraceae & 2 & - & - & - & 2 & - & 6 & 5 & 7 & 3 & 5 & 5 & 5 & 110 \\
\hline Amphitecna & Bignoniaceae & - & 1 & - & - & - & - & - & - & 2 & - & - & - & 3 & 110 \\
\hline Billia & Hippocastanaceae & - & 1 & - & - & 2 & - & 1 & 2 & - & - & 3 & - & 3 & 110 \\
\hline Melastomataceae & Melastomataceae & - & 3 & - & - & - & - & - & 1 & 5 & - & - & 1 & 4 & 110 \\
\hline Miconia & Melastomataceae & - & - & - & - & - & - & 2 & - & - & - & 3 & - & - & 110 \\
\hline Mortoniodendron & Tiliaceae & - & - & - & - & 1 & - & - & 2 & - & - & - & - & 2 & 110 \\
\hline Parathesis & Myrsinaceae & - & - & - & - & - & - & - & 1 & 1 & - & 2 & - & - & 110 \\
\hline Persea & Lauraceae & - & - & - & - & 1 & - & 5 & - & - & 4 & - & - & - & 110 \\
\hline Flacourtiaceae & Flacourtiaceae & - & 1 & - & - & - & - & - & - & 1 & 5 & 2 & - & - & 111 \\
\hline Casearia & Flacourtiaceae & - & - & - & - & - & - & - & - & - & - & - & 3 & 6 & 111 \\
\hline Inga & Mimosaceae & - & - & - & 3 & - & - & - & - & - & 3 & 4 & 1 & - & 111 \\
\hline Calophyllum & Clusiaceae & - & - & - & - & - & - & - & - & - & 2 & - & - & - & 111 \\
\hline Piper & Piperaceae & - & - & - & - & - & - & - & - & 1 & 1 & - & 2 & - & 111 \\
\hline Xylosma & Flacourtiaceae & - & - & - & - & - & - & - & - & - & 2 & - & - & - & 111 \\
\hline Acalypha & Euphorbiaceae & - & - & - & - & - & - & - & - & - & - & 3 & - & - & 111 \\
\hline Ardisia & Myrsinaceae & 2 & 1 & - & - & - & - & - & - & - & - & - & 4 & - & 111 \\
\hline Cecropia & Cecropiaceae & - & - & - & - & - & - & - & - & - & 4 & 6 & - & 3 & 111 \\
\hline Clarisia & Moraceae & - & - & - & - & - & - & - & - & - & - & - & 4 & - & 111 \\
\hline Guarea & Meliaceae & - & - & - & - & - & - & - & - & - & - & - & 4 & - & 111 \\
\hline Guettarda & Rubiaceae & - & - & 1 & - & - & 1 & - & - & 2 & - & - & 4 & - & 111 \\
\hline
\end{tabular}




\begin{tabular}{|c|c|c|c|c|c|c|c|c|c|c|c|c|c|c|c|}
\hline Hasseltiopsis & Flacourtiaceae & - & - & - & 4 & - & - & - & - & 1 & 2 & 5 & - & - & 111 \\
\hline Macrohasseltia & Flacourtiaceae & - & - & - & - & - & - & - & - & - & - & - & - & 6 & 111 \\
\hline Malvaviscus & Malvaceae & - & - & -. & - & - & - & - & - & - & - & - & 3 & - & 111 \\
\hline Pseudolmedia & Moraceae & - & - & - & - & - & - & - & 5 & - & 6 & 6 & - & - & 111 \\
\hline Rinorea & Violaceae & - & - & - & - & - & - & - & - & - & - & - & 4 & - & 111 \\
\hline Senecio & Asteraceae & - & - & - & - & - & - & 1 & - & - & 2 & - & - & 2 & 111 \\
\hline Symphonia & Clusiaceae & - & - & - & - & - & - & - & - & - & - & 4 & - & 2 & 111 \\
\hline Symplocos & Symplocaceae & - & - & - & - & - & - & - & - & - & - & - & 1 & - & 111 \\
\hline TWINSPAN- & & 0 & 0 & 0 & 0 & 0 & 0 & 0 & 0 & 0 & 1 & 1 & 1 & 1 & \\
\hline division & & 0 & 0 & 0 & 0 & 0 & 0 & 1 & 1 & 1 & 0 & 0 & 0 & 1 & \\
\hline
\end{tabular}

